\title{
Geological conditions and characteristics of the Nubia Sandstone aquifer system and their hydrogeological impacts, Tushka area, south Western Desert, Egypt
}

\author{
Tarek A. Aggour ${ }^{1}$, Ezzat A. Korany ${ }^{2}$, Sayed Mosaad ${ }^{1 *}$ and Alan E. Kehew ${ }^{3}$ \\ ${ }^{1}$ Geology Department, Desert Research Center, Matariya, Cairo, Egypt (B.O.P. 11753) \\ ${ }^{2}$ Geology Department, Faculty of Science, Ain Shams University, Cairo, Egypt \\ ${ }^{3}$ Department of Geosciences, Western Michigan University, USA
}

A R T I C L E I N F O

Article history:

Received 13 September 2012

Accepted 24 October 2012

Keywords:

Nubia Sandstone;

arenites;

wackes.

\begin{abstract}
A B S T R A C T
Nine lithostratigraphic sections were measured and sampled from the Tushka area and two geological cross-sections were constructed. They revealed that the area consists of a sedimentary succession ranging in age from the Paleozoic to Quaternary and overlies the Precambrian Basement rocks. The Nubia Sandstone in the subsurface comprises three water-bearing formations, namely; Gilf, Abu Simble and Lake Nasser. They range in age from the Paleozoic to the Upper Cretaceous. Petrographically, the Nubia Sandstones are formed of arenites and less commonly wackes having well-developed porosity and permeability. In the study area the structural setting plays an important role in the groundwater configuration. The NW-SE faults are responsible for the groundwater recharging from Lake Nasser. Local fault blocks were developed and resulted in the formation of different types of groundwater aquifers which are laterally and vertically connected.
\end{abstract}

\section{Introduction}

Tushka area lies in the southern part of the Western Desert, adjacent to the Egyptian-Sudanese boundaries. It lies between lats. $22^{\circ} 15^{\prime} \mathrm{N}$ and $23^{\circ} 15^{\prime} \mathrm{N}$ and longs. $31^{\circ}$ $00^{\prime} \mathrm{E}$ and $32^{\circ} 00^{\prime} \mathrm{E}$. The area is accessible by number of asphaltic and paved roads as well as desert tracks (Fig. 1). Few works were published on the study area dealing with its stratigraphy, whereas several studies were conducted on Aswan and north of the study area. Among these are those of Russeger ${ }^{[1]}$, Attia ${ }^{[2]}$, El Naggar ${ }^{[3]}$, Issawi and Jux ${ }^{[4]}$, El Nashrity ${ }^{[5]}$, Kiltzch et al. ${ }^{[6]}$, Ahmed et al. ${ }^{[7]}$ and Issawi and Osman ${ }^{[8]}$. The surface of the area is dominated by sedimentary rocks ranging from the Paleozoic to the Quaternary, with some exposures of igneous and metamorphic rocks belonging to the Late Precambrian, Phanerozoic, Late Cretaceous and Tertiary (Fig. 2).

The present work is focused mainly on the geological conditions, characteristics and the prevailing structures of the exposures of the Nubia Sandstone. Nine lithostratigraphic sections were measured, sampled and

\footnotetext{
* Corresponding author.

E-mail address: alfaran2010@yahoo.com
}

described petrographically. Two cross-sections are constructed using the data obtained from the boreholes drilled by the Aswan High Dam Authority [9] and the Research Institute for Groundwater (RIGW, 1998-2002). The lithological characteristics and geologic structures were defined and their impacts upon the Nubia Sandstone aquifer were investigated.

\section{Materials and Methods}

In the present work careful investigations of 125 collected from nine exposed stratigraphic sections from the study area. Each section was described, measured and sampled in the field. Thirty five samples from those were microscopically examined in the laboratory for identification of petrographic and diagenetic characteristics. Most of the thin section stains with blue dye to determine the porosity. The microscopic method involves the use of a microscope (Leitz Laborlux 12 pol) with natural light and crossed-nicols light (XPL) capabilities to identify composition, proportions, and size of detrital grains, authigenic materials, structures and textures and porosity. Images are captured using a Leica DFC 290 camera and its associated software (Leica Application Suite, version 2.5.0 R1, Leica Microsystems). 
The Ruska Gas peremeameter of geophysics department in Ain Shams University was used to measure the permeability of fifteen consolidated Nubia Sandstone samples. On the other hand the saturation method was used to measure the porosity for 34 samples.

\section{Lithostratigraphic succession}

The lithostratigraphic sedimentary succession of the area around Khor Tushka is underlained by the Precambrian basement rocks. The Paleozoic rocks are represented in the subsurface by the Gilf Formation unconformably underlying the Cretaceous rocks which are differentiated into the Abu Simble, Lake Nasser and Sabaya Formations (Lower Cretaceous) and the Kiseiba formation (Upper Cretaceous). Nine lithostratigraphic sections were measured and sampled around Khor Tushka in order to define the lithologic characteristics of the exposed Nubia Sandstone rocks with a special atten-

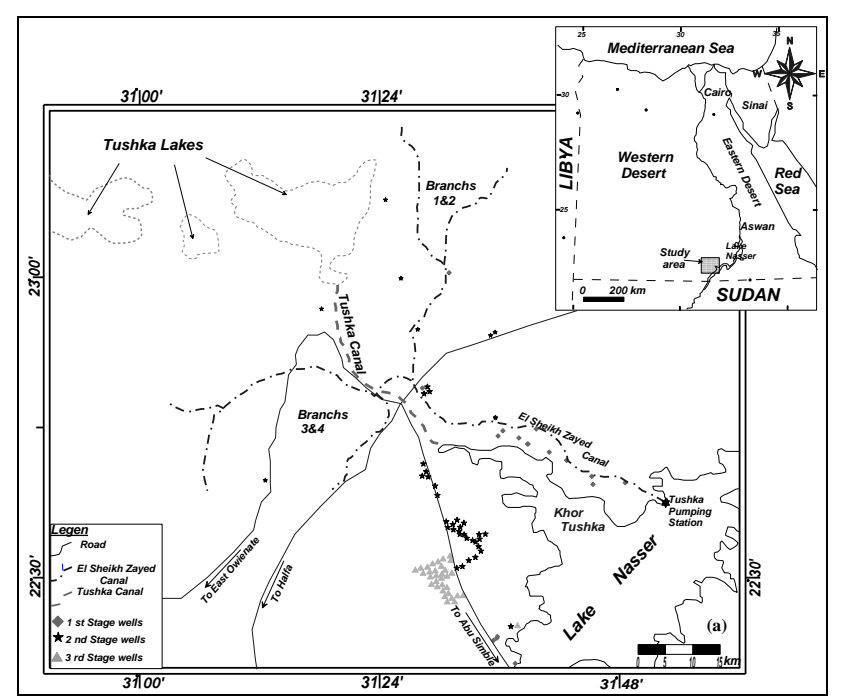

tion paid to the Lower Cretaceous rocks. Based on the nomenclature adopted in the geologic map of Conoco ${ }^{[10]}$, the lithofacies characteristics of the studied exposed rock units (from base to top) are described (Fig. 2).

\section{1- The Precambrian rocks}

The Precambrian basement rocks are exposed along the major uplift trending northeast - southwest (NakhlaiAswan uplift). They are formed of crystalline igneous and metamorphic rocks of the Arabian-Nubia shield ${ }^{[11]}$. A basement relief map is constructed based on the information obtained from 32 fully penetrating wells drilled in the study area by the Aswan High Dam Authority ${ }^{[9]}$ and the Research Institute for Groundwater [12] as well as the altitudes of the exposed basement rocks to the west (Fig.3). The constructed map indicates that the basement surface slopes regionally to the southeast of Tushka area.

\section{2- The Paleozoic (Carboniferous) Rocks (The Gilf Formation)}

The term Gilf Formation was first introduced by Issawi [13] to describe the sandstone section exposed at the nearly vertical cliff of the Gilf Plateau in southwest Egypt (It is dated Carboniferous by Issawi and Jux ${ }^{[4]}$ ). The Formation is exposed to the north of the study area with a thickness reaching $35 \mathrm{~m}$. It is encountered in the subsurface, overlying the Precambrian basement rocks with a thickness ranging from $60 \mathrm{~m}$ (Ob11D) to $160 \mathrm{~m}$ (W-2) to the north of Khor Tushka (Fig. 11). The Gilf Formation is formed mainly of brown to yellowish brown sandy mudstone, sandstone and clay. Occasionally, this formation thins or disappears giving rise to the Lower Cretaceous Abu Simble Formation which overlies directly the Precambrian rocks.

Fig. 1: Location map of the study area and drilled wells.

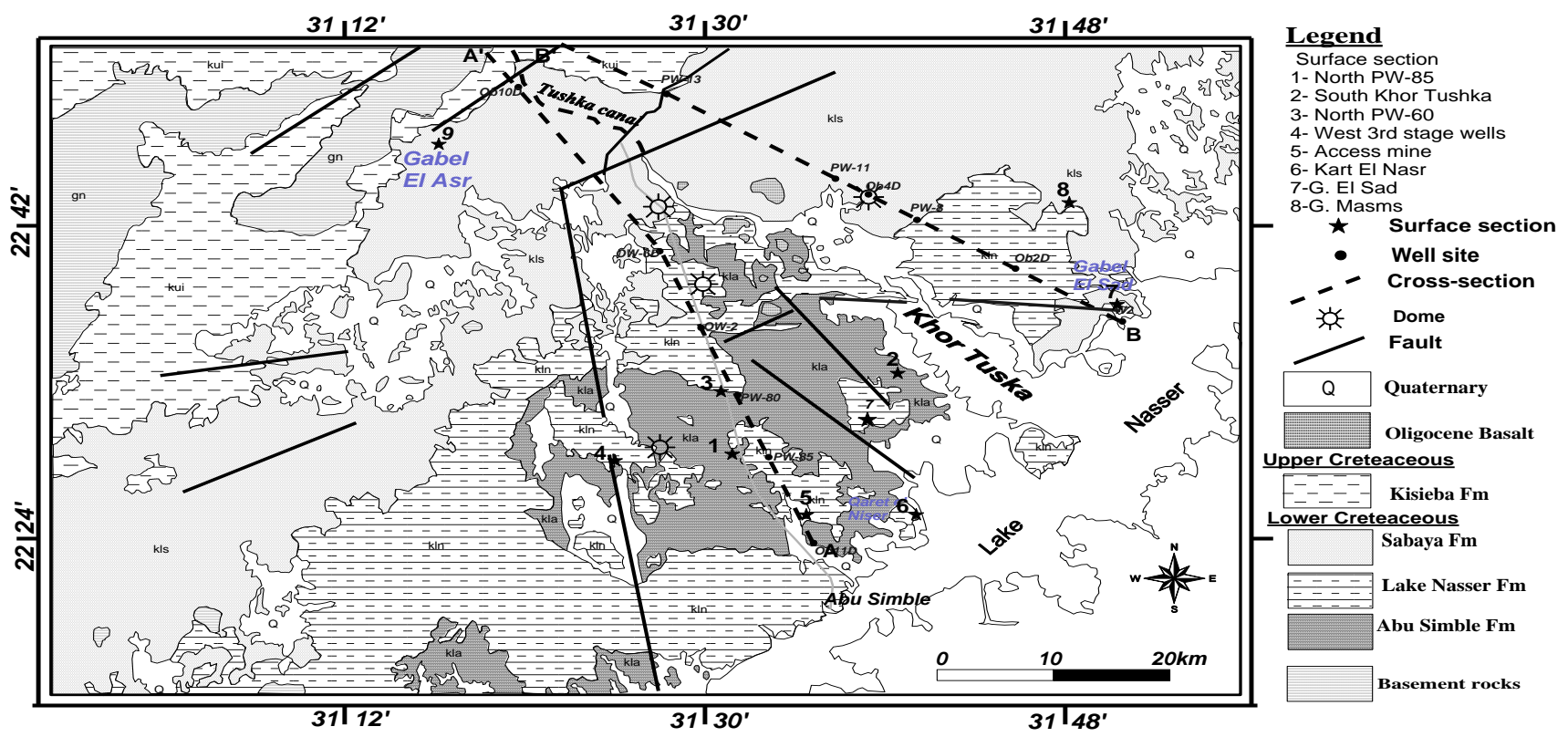

Fig. 2: Geologic map for Tushka region (Modified after Conoco ${ }^{[10]}$, local area adjacent to Lake Nasser at Kart El Naser section, Abu Simble Fm changed into Lake Nasser Fm by present field surveying). 


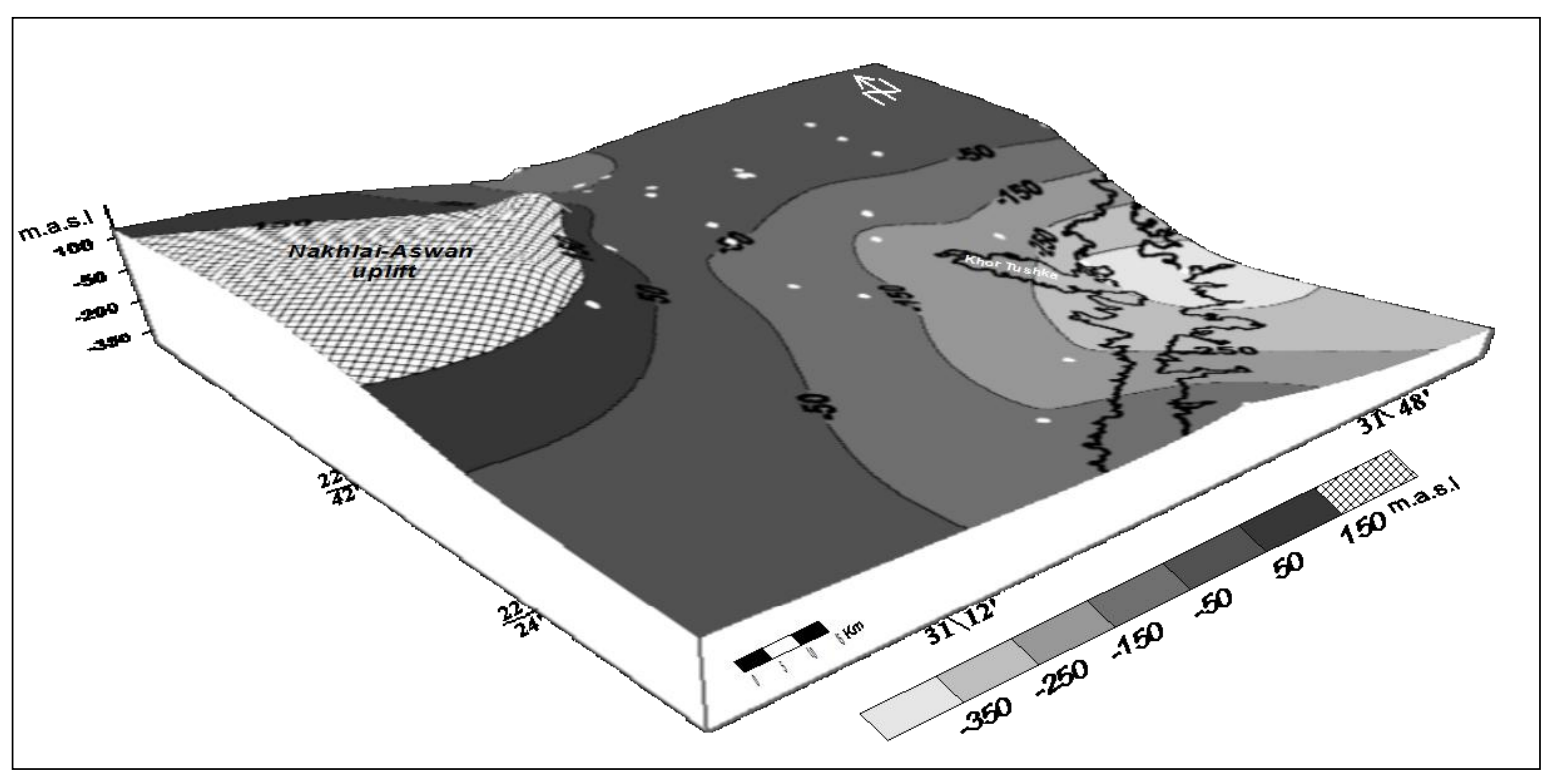

Fig. 3: Basement relief map of the study area (After Korany, et al., ${ }^{[14]}$ in press).

\section{3- The Cretaceous rocks}

Lower and Upper Cretaceous rock units forming the main bulk of Nubia Sandstone series, are exposed on the surface or encountered in subsurface in Tushka area.

\section{1- The Lower Cretaceous rocks}

The Lower Cretaceous rocks are widespread in the study area and represent the major part of the sedimentary succession. They are differentiated into the Abu Simble, Lake Nasser and Sabaya Formations (from base to top). These formations were sampled at nine sections exposed within the study area (Fig. 2) to elucidate their lithological characteristics.

3.1.1- The Abu Simble Formation: (Neocom-Barrem) The Abu Simble Formation was defined by the Egyptian Geological Survey to describe a thickness of $180 \mathrm{~m}$ of sandstone along Abu Simble escarpment on the eastern side of Lake Nasser. This formation covers vast parts of the study mapped area south of Khor Tushka. It was measured, sampled and described at sections defined at the NW well 85 (1), South Khor Tushka (2), North well 60 (3) and west third-stage wells (4). Its thicknesses changes from $30 \mathrm{~m}$ at north well 60 section, $52.5 \mathrm{~m}$ at west third stage wells section, $64.5 \mathrm{~m}$ at south Khor Tushka section and 87.45 $\mathrm{m}$ at NW production well 85 (Figs. $2 \& 4$ ). The Abu Simble Formation is composed mainly of a sequence of sandstone, ferruginous sandstone and siltstone beds with occasional conglomerate bands. The sandstone and ferruginous sandstone beds are varicolored (yellowish brown to reddish brown), medium to very coarse-grained with granules and pebbles. Most of the sandstone beds are rich in iron oxides that give them a yellowish-brown to dark-reddish brown color and sometimes form nodules within the formation. The siltstone beds are varicolored (dark gray to violet), hard and sometimes alternate with thin sandstone beds.

The Abu Simble Formation shows thin laminations in the lower part and thick bedded at the upper portion and cross-bedding (tabular and trough) is common (Fig. 4). Petrified plants are present in some areas. The lithological properties and the sedimentary structures as well as the presence of petrified plants indicate that the Abu Simble Formation was deposited under fluvial environmental conditions.

\subsection{2- The Lake Nasser Formation (Barrem-Aptian)}

The Lake Nasser Formation crops out over the Nubia plain in the study area (Fig. 2). Its type locality lies at the eastern side of Lake Nasser around Geble um Kharite and on the western side between Geble Masmas and the Egyptian-Sudan borders. It is underlain by the Abu Simble Formation and overlain by the Sabaya Formation. Four surface sections were measured and sampled at; the west third stage wells (4), North 60 well (3), Kart El Nasr (6) and Access mine, with thicknesses being 22.4, 63.65, 54 and $45 \mathrm{~m}$, respectively (Figs. 2 \& $5)$. The succession is built up of ferruginous siltstone and ferruginous sandstone. The ferruginous siltstone layers are varicolored (whitish gray, gray, and dark reddish brown), thinly-laminated and contain iron concretions which reach a very large size in the section of west third stage wells. These concretions leave empty cavities as a result of weathering processes (Fig. 5). The sandstone beds are mainly brown, fine to very coarsegrained, laminated and cross-bedded (planar type) near the base of the sections. Massive sandstone beds are also common. The sedimentary features suggest that the Lake Nasser Formation were deposited along a coastal margin, where the conditions fluctuated from highenergy (marked by sandstone deposition) to more slack water (marked by siltstone and mudstone deposition).

\subsection{3- The Sabaya Formation (Albian-Cenomian)}

The term Sabaya Formation was first applied by Barthel and Boettcher ${ }^{[15]}$ to define the sandstone sequences cropping out at G. Qulu El Sabaya in south Dakhla Oasis. 

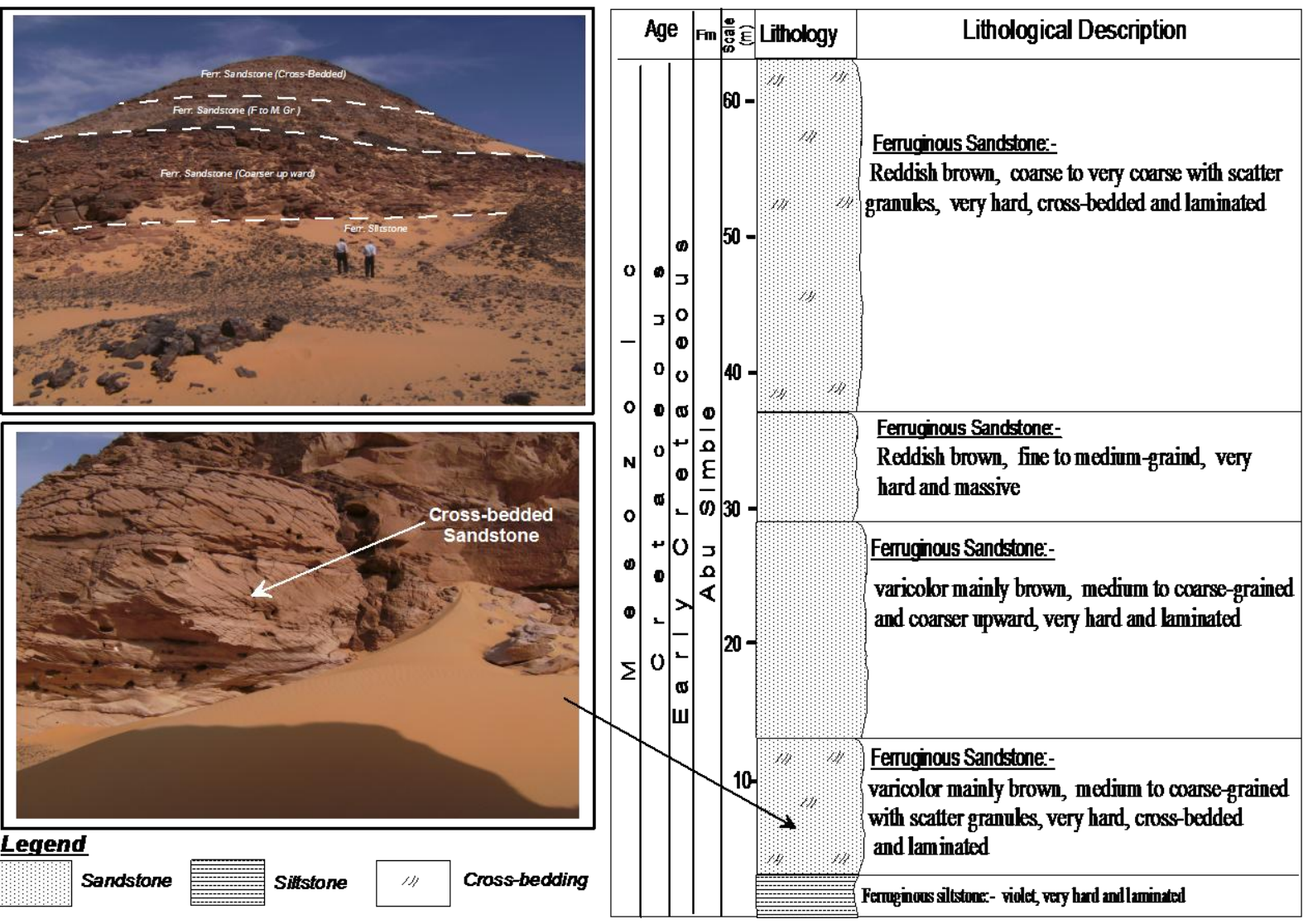

Fig. 4: Field photographs and lithostratigraphic section (2) South Khor Tushka.

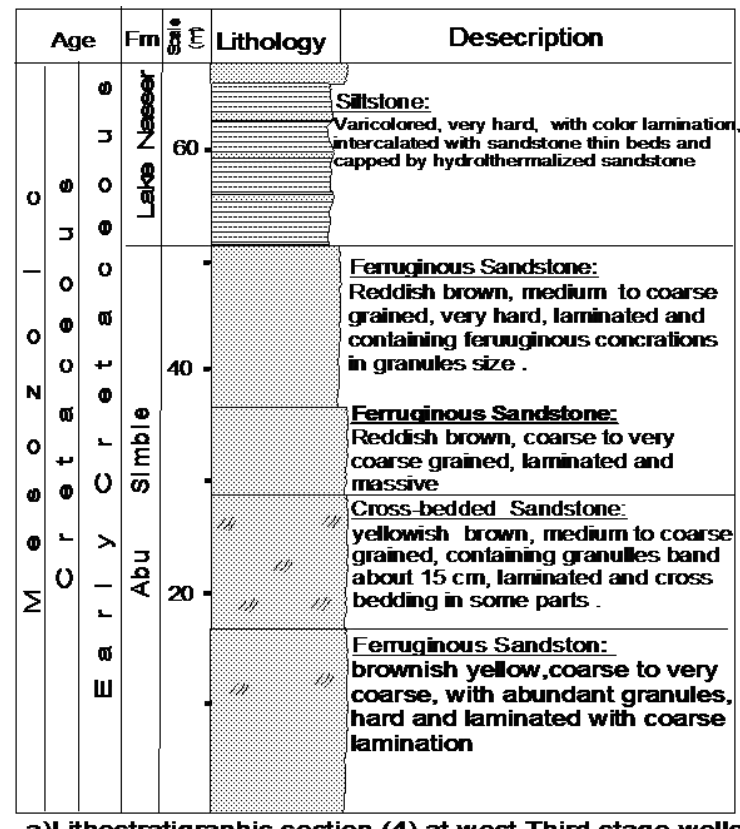

a)Lithostratigraphic section (4) at west Third stage wells

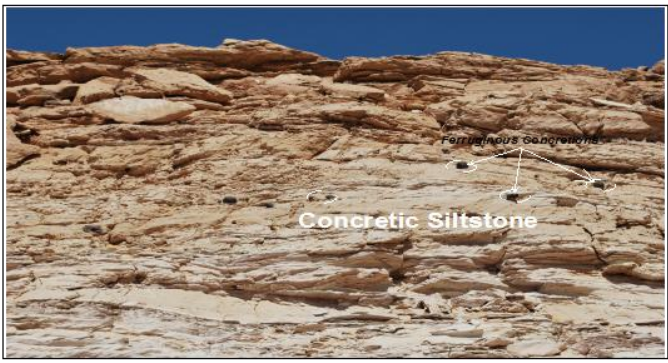

c) Concretic Siltstone within Lake Nasser Fm

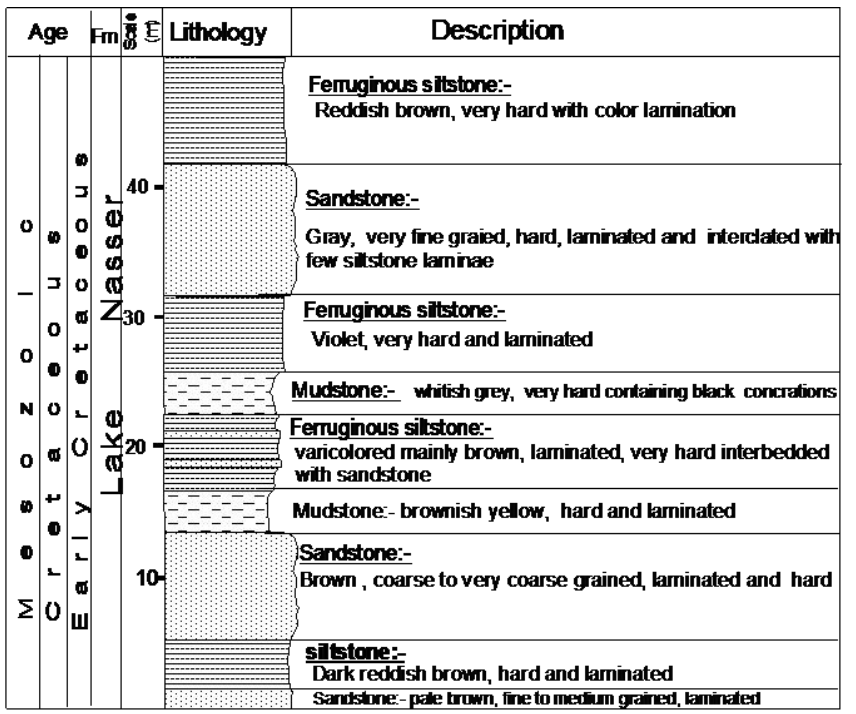

b) Lithostratigraphic section (6) at Kart El Nasr

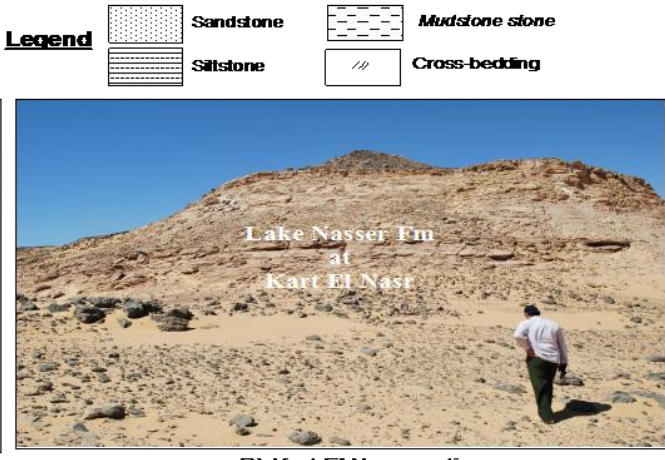

D) Kart EI Nasr section

Fig. 5: Field photographs and Lithostratigraphic sections of the Abu Simble and Lake Nasser formations. 
The Sabaya Formation crops out to the north of Khor Tushka and to the west of the Wadi Halfa road. It was sampled from the surface sections of G. El Sad (7) and G. Masms (8) with thicknesses of $97.3 \mathrm{~m}$ and $144.45 \mathrm{~m}$, respectively (Figs. $2 \& 6$ ). Lithologically, the lower part of the Sabaya Formation in the study area consists mainly of sandstone, ferruginous sandstone with thin beds of conglomerate ( $\sim 00 \mathrm{~cm}$ thick) encountered (Fig. $6 \mathrm{c})$. The sandstone is varicolored (mainly brown), coarse to very coarse-grained, commonly ferruginous containing scattered granules and pebbles, cross-bedded (trough and tabular types) and laminated. On the other hand, the upper parts are composed mainly of finer grains sediments represented by siltstone, and fine to medium-grained sandstone that are intercalated with thin beds of violet ferruginous mudstone (paleosol) rich in manganese and iron oxides.

The depositional environment of the lower parts of the Sabaya Formation reflect a braided river conditions and sheet flows over channel banks for the upper parts which are marked by alternating siltstone, sandstone and mudstone intercalations. Similar interpretations were given by Ahmed et al. ${ }^{[7]}$ and Issawi and Osman ${ }^{[8]}$ for the northern parts of the study area.

3.2- The Upper Cretaceous rocks (Kiseiba Formation) The upper Cretaceous rocks in the area of study are represented by the Kiseiba Formation. It has a $150 \mathrm{~m}$ thick at its type locality (the escarpment of Bir Kiseiba). The Kiseiba Formation is recorded at the northwestern part of the study area. Lithologically, it is composed at its lower part of a succession of shale beds alternating with a few layer of siltstone, while the upper part becomes more carbonaceous and is composed of fossilferrous limestone, calcareous shale and marl. Two fossilferrous beds are recorded, one in the lower part (Oyster fossils) and the other at the base of the fossilferrous limestone (Cephalopods shells).

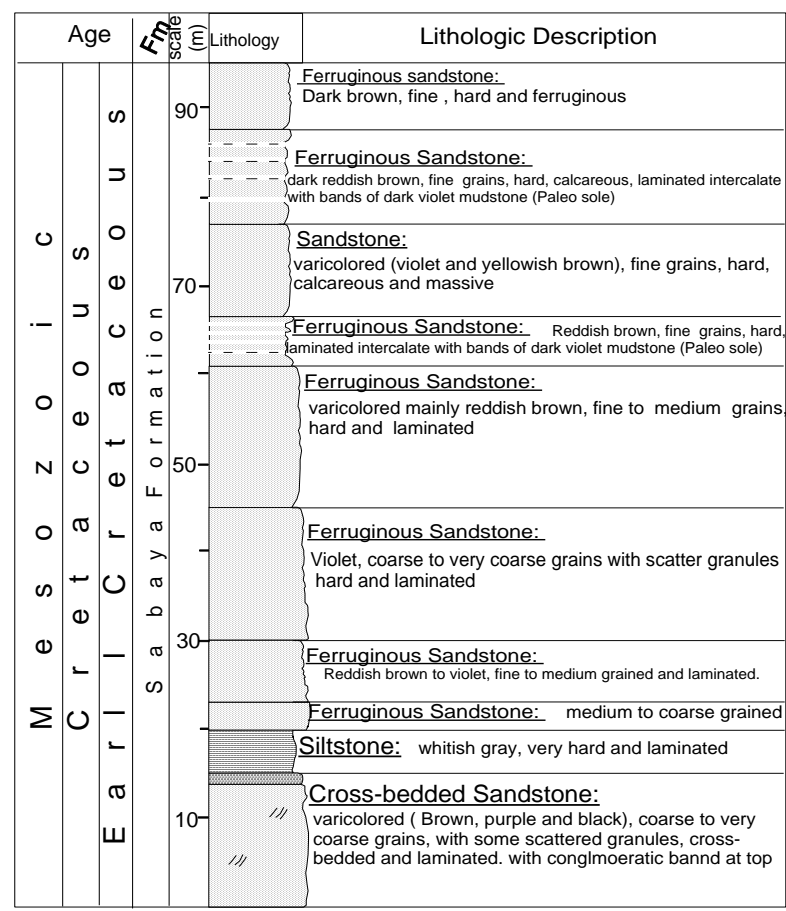

6a) Lithostratigraphic Section (7) at G.EI Sad Legend

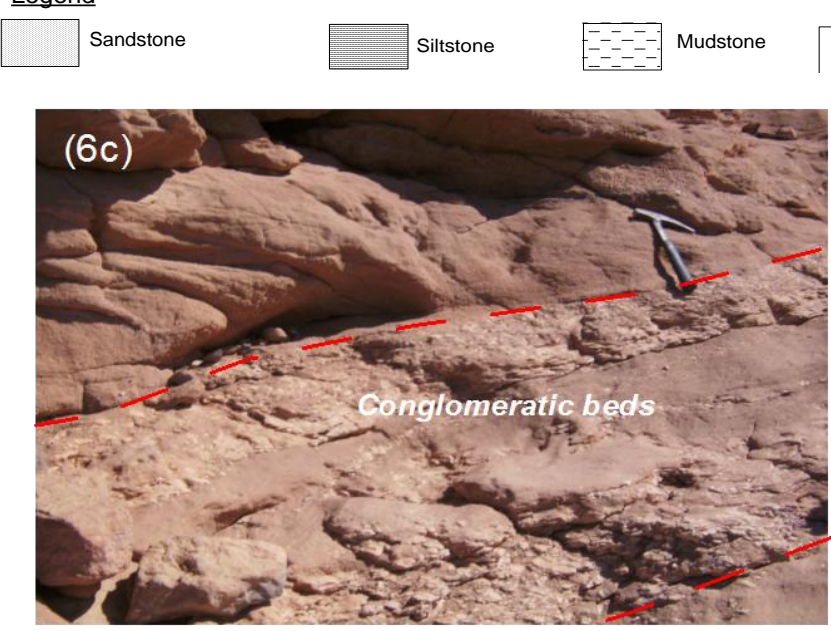

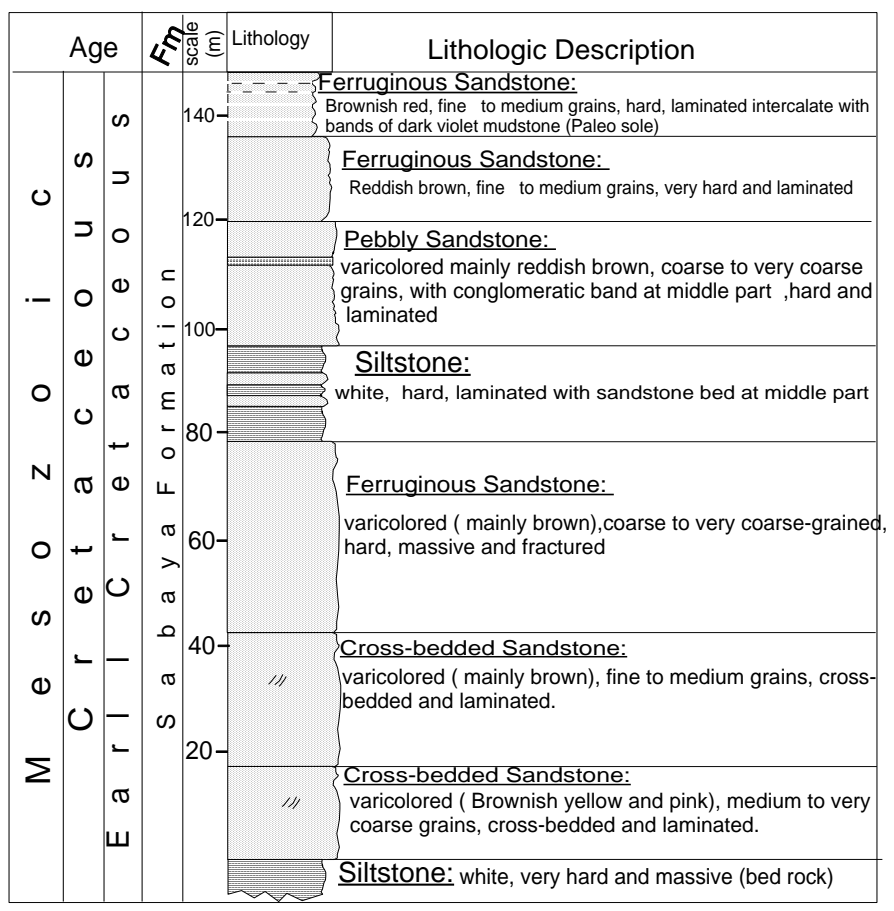

6b) Lithostratigraphic Section (8) at G.Masms

Cross-bedding

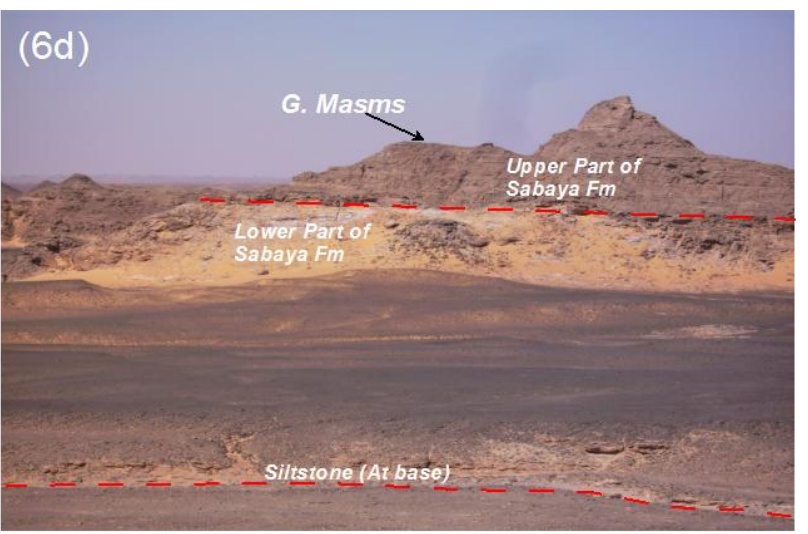

Fig. 6: Field photographs and lithostratigraphic sections of the Sabaya Formation. 
The data collected from the fully and partially penetrating wells in the study area reveal that the Nubia Sandstone in the subsurface is locally composed of sand and ferruginous sandstone with clay intercalations forming three successive water-bearing formations, namely; the Gilf, Abu Simble and Lake Nasser to the south of Khor Tushka (Fig. 11).

\section{4- The Cenozoic rocks}

\section{The Oligocene basalt (Tertiary volcanism)}

These dark gray basaltic rocks are widespread especially near the head of Khor Tushka, near G. El Sad and in the southwestern part of the study area (to the west of the third stage wells) where numerous darktoned low hills are scattered and basalts are found as sheets overlying or intrerbedded with the Nubia Sandstone.

\section{5- The Quaternary deposits:}

Very thin covers of Quaternary deposits are recognized in Tushka area. They are represented by sand accumulations and alluvial sediments. Sand accumulations are formed of gravelly sand cover between the hilly areas that are composed mainly of poorly sorted, fine to very coarse sand with abundant gravels derived from the various older rocks. Sand sheets cover vast areas and are composed mainly of very well-sorted sand, medium to coarse-grained with rippled cross lamination. Alluvial sediments are deposited as a result of water floods along the shore of both Lake Nasser and the new Tushka lakes formed in the Tushka depression. The alluvial deposits consist mainly of silt and clay which display mud cracks upon drying.

\section{Microfacies associations in the Nubia Sandstone}

Based on the classification proposed by Pettijohn et al. [16], the studied Nubia sandstones are composed of arenites and, less commonly, wackes (Figs. 7 and 8). The following microfacies are recognized:

1.Quartz arenites they comprise $49 \%$ of the studied sandstone in Abu Simble, Lake Nasser and Sabaya formations. The rocks are formed of quartz grains (more than 95\%) with less than 3\% feldspar (altered orthoclase and plagioclase) and about 1-3\% rock fragments (polycrystalline quartz). The quartz grains are commonly clear, rarely cloudy and show bimodal particle size distributions (Figs. 8A \& B). They are moderately to very well-sorted and rarely poorlysorted. Ferruginous and argillaceous cements are common whereas carbonates are rare. The porosity $(7-28 \%)$ is represented by interconnected pores which represented in a relatively high permeability (Fig. 8B).

2. Subarkoses they comprise $17 \%$ of the studied Nubia sandstone. The rocks are composed of $75-89 \%$ quartz grains, $7-15 \%$ feldspar (mainly orthoclase) that shows various degrees of alteration and less than $6 \%$ lithic fragments (Fig. 8C \& D). The majority of the grains are medium to very coarse. The quartz grains are monocrystalline, rarely polycrystalline, and show

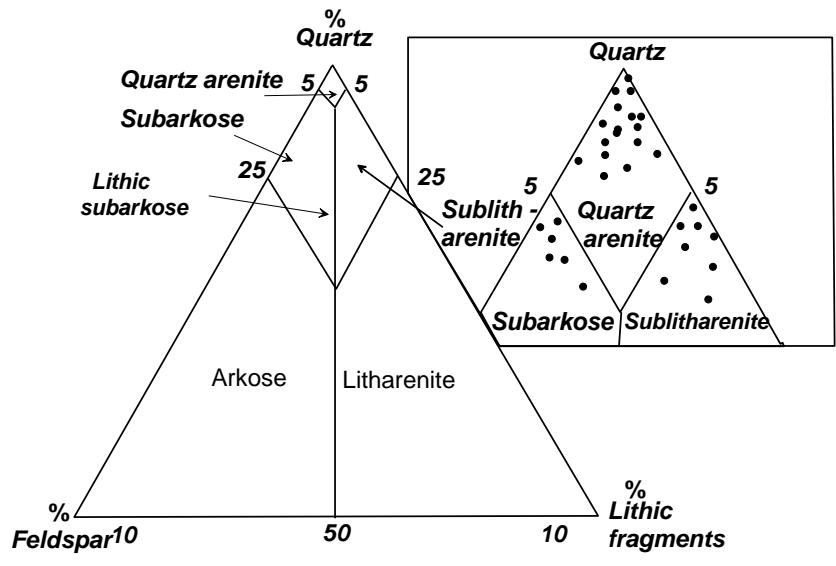

Fig. 7: Classification of Nubia sandstones, Tushka area (Applying Pettijohn et al., ${ }^{[16]}$, classification).

uniform and undulose extinction. The cements are commonly ferruginous, argillaceous and rarely quartz overgrowths. The subarkoses have intergranular porosity ranging between 13 to $30 \%$. Most of the pores are interconnected giving relatively high permeability

3. Sublitharenites they make up $23 \%$ of the studied Nubia sandstones. The rocks are composed of $75-90 \%$ quartz grains, 10-12\% rock fragments which are derived mainly from shale or mudstones that show various degrees of alterations and 1-2\% feldspar (altered orthoclase) (Fig. 8E \& F). The majority of the grains are medium to very coarse; rarely fine, angular to subround and subeqant to slightly elongate. Cements are commonly ferruginous and argillaceous. Porosity (15-25\%) of intergranular. The pores are interconnected to give relatively high permeability.

4. The wackes they comprise $11 \%$ of the studied Nubia sandstones. They consist mainly of quartz wacke consisting of $60-77 \%$ quartz grains, $3-5 \%$ altered feldspar with very rare lithic fragments all embedded in a fine-grained matrix made up of silt-sized quartz grains and clay (Figs. $8 \mathrm{G} \mathrm{\&} \mathrm{H}$ ). The quartz grains are mostly medium to very fine, the majority of are subangular to rounded and subequant to elongated. Cements are mainly ferruginous and argillaceous. The primary porosity of wackes is reduced as a result of mechanical infiltration of the finer sediments, while the secondary porosity (mainly vuggy) ranges between $5-15 \%$.

The studied Nubia sandstones were affected by various diagenetic processes, both physical (compaction) and chemical (pressure solution, cementation, alteration). Mechanical processes represented in compaction bending of mica flakes and pseudoplastic deformation of mud intraclasts, which resulted in the formation of a pseudomatrix (Fig. 8F). On the other hand, ferruginous cements are developed as result of invasion of iron-rich solutions (Figs. 8A, D \& H). Ferruginous and argillaceous cements are common in most of the studied sandstones fill the pore spaces and have, thus decreased the intergranular porosity. Alteration of the feldspar is a common feature, especially in subarkoses (Fig. 8D). 

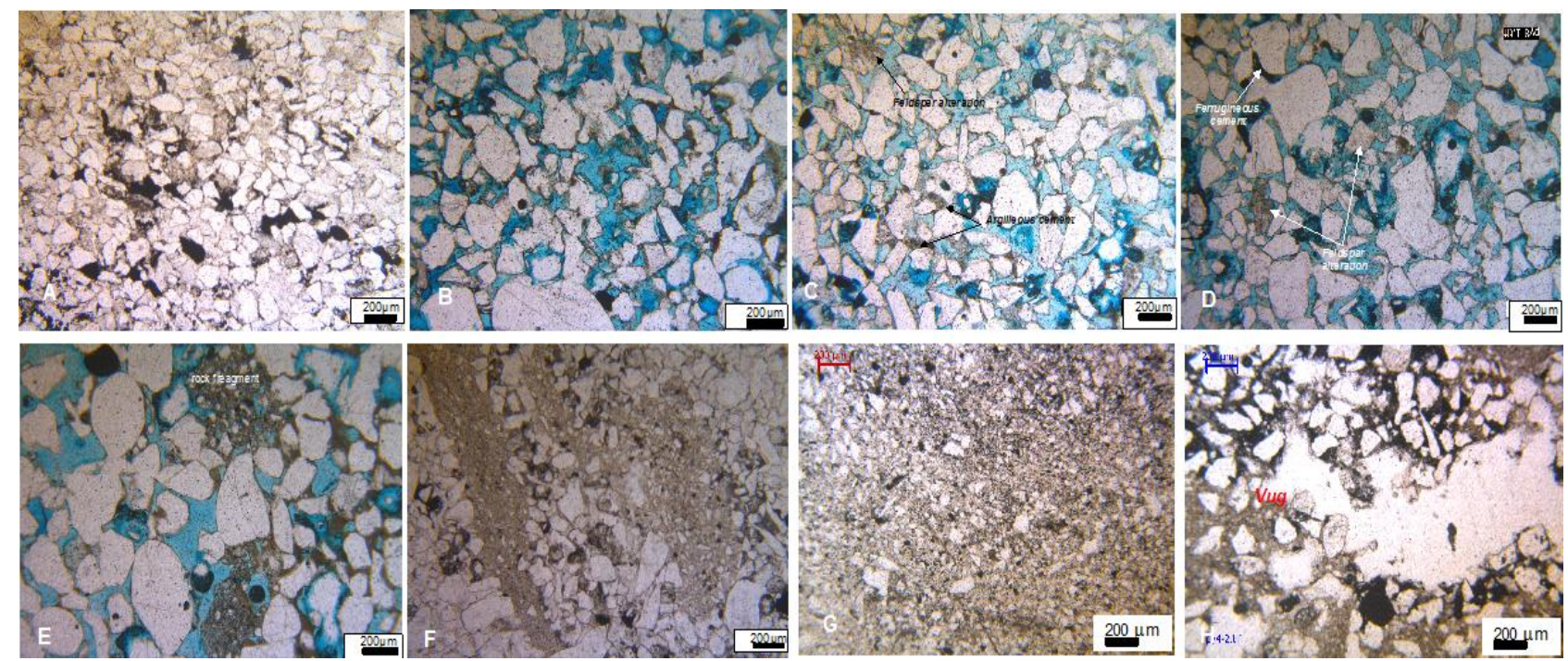

Fig. 8: Nubia sandstone microfacies associations

- $(A \& B)$ Quartz arenites: (A) Medium to coarse sandstone of the Abu Simble Formation. The intergranular porosity is masked by iron oxide cement, PPL;. (B) coarse to very coarse sandstone of the Lake Nasser Formation with much intergranular pores, PPL.

- (C\&D) Subarkoses: (C) Medium to very coarse sandstone, with common point and straight grain contacts and argilleous and ferruginous cements. Abu Simble Formation, PPL; (D) Coarse to very coarse-grained, with straight grain contacts, common feldspar alteration and high pores, Lake Nasser Formation, PPL.

- (E\&F) Sublitharenites (E) medium to very coarse-grain with much intergranular porosity, argillaceous and ferruginous cements; iron oxides form thin coating of quartz grains, Abu Simble Formation, PPL.; (F) very coarse sand to granule sized lithic fragments and containing fine matrix plugs intergranular pores, Sabaya Formation, PPL.

- $(\mathrm{G \& H})$ : Wackes $(\mathrm{G})$ matrix plug the Intergranular pores of the sandstone, Lake Nasser Formation, PPL; (H) Vuggy porosity in the Sabaya Formation, PPL.

The calculated porosity of the collected 34 samples ranges from 13.6 and $30.73 \%$. It varies from $18.34 \%$ to 30.49 for the Abu Simble Formation and from 16.62\% to $27.37 \%$ for the Lake Nasser Formation and from $13.59 \%$ to $30.73 \%$ for the Sabaya Formation. The permeability was calculated, using Ruska Gas Permeameter. It ranges from 0.38 to 2.168 darcy for the Sabaya Formation and from 0.507 to 2.028 darcy for the Lake Nasser Formation and from 0.8919 to 2.168 darcy for the Abu Simble Formation. The hydraulic conductivity was determined from the analysis of pumping tests. It ranges between $2.44 \mathrm{~m} /$ day and 10.66 $\mathrm{m} /$ day for the Nubia Sandstone aquifer system.

\section{Geologic structures:}

Different structural elements were investigated on the surface and subsurface of Tushka area. Among these are; Basement uplifts, folds, ring forms and the structural lineation. They are described in the following:

\section{Uplift}

The basement uplift is represented by the NakhlaiAswan uplift. It is formed mainly of some relatively large bodies of basement rocks (Fig. 2). These major uplifted blocks trend NE-SW and are about $300 \mathrm{~km}$ long. They are composed mainly of Aswan Pink granite and are covered at the east and north by the Nubia sandstones. These large blocks are bounded by N40ES40W normal faults with downthrows due east and west (Fig. 2).

\section{Faults}

Three major fault sets were recognized in the study area trending generally NE-SW, E-W and NW-SE (Fig. 2). The NE-SW faults are related to the Gulf of Aqaba trend. Most of these faults have vertical or horizontal displacement and they bound the granitic rocks in the area of the Nakhlai-Aswan uplift. The NW-SE faults are widespread in the area south to khor Tushka and related primarily to khor Tushka structure that is affected by the Red Sea structure. They are of the normal-slip type having vertical relief and are usually arranged in a steplike pattern mostly with downthrown to the east. The E$\mathrm{W}$ faults are mainly of the normal type and are recorded to the north of Khor Tushka.

\section{Fold and Ring forms}

Different types of folds were recognized in the field and through examination of satellite images. They have NNESSW and N-S trends. The sedimentary beds dip $15-45^{0}$ forming limited basins and domes trending E-W and NESW (Fig. 9).

Ring forms are recorded within the area of study. They may represent either dome structure or basin form or they are delineated in some localities which are covered by Nubia sandstone beds. The Domes appear in the area of study in the ring form structures. They represent the positive structural areas that given rise to weakness zones at their crests where weathering and erosion processes are active. The basin forms are widespread in the ring forms in the area and preserved as a result of differential weathering. 

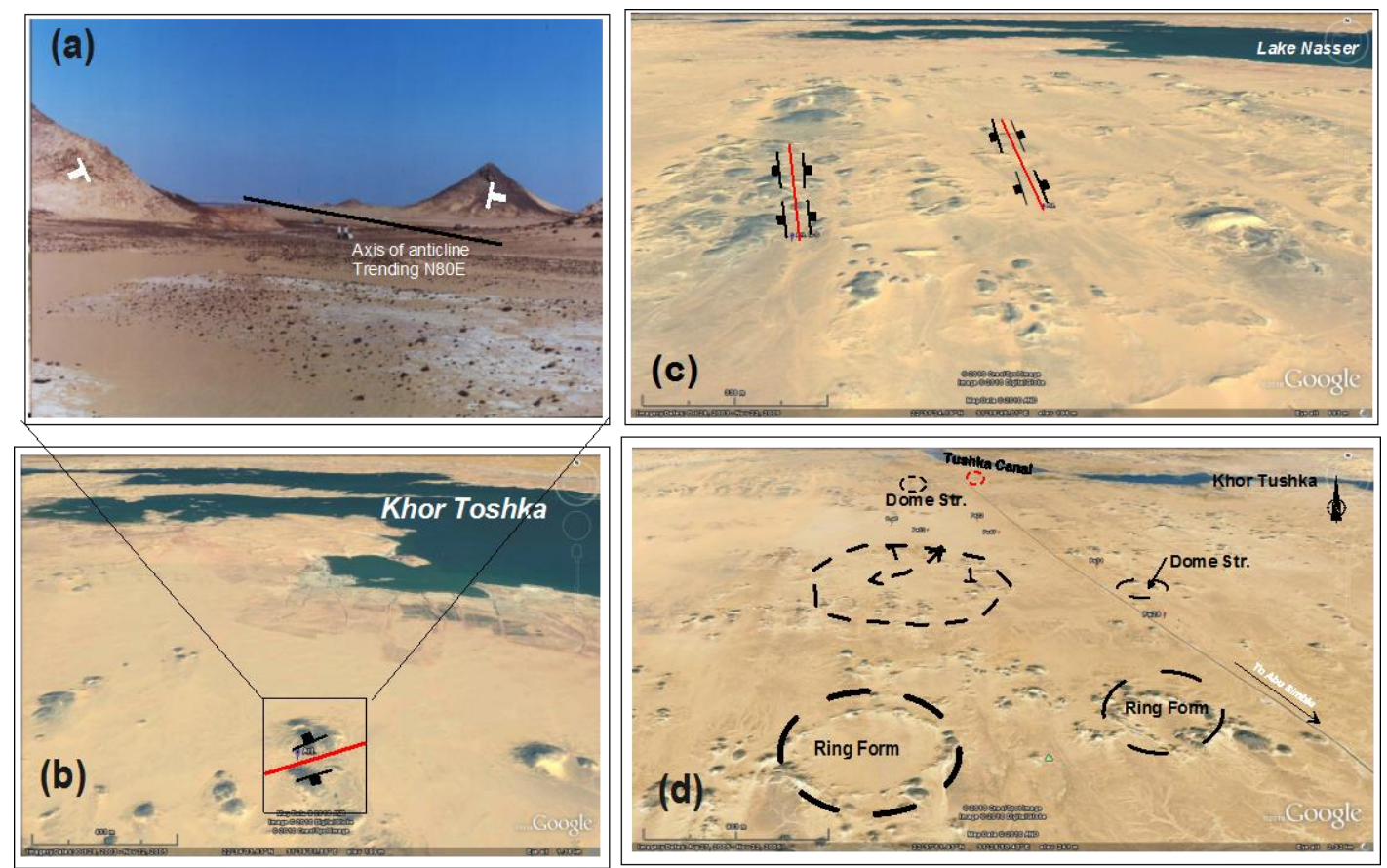

Fig. 9: A Field photograph and satellite images showing anticline, domes and ring forms south Khor Tushka
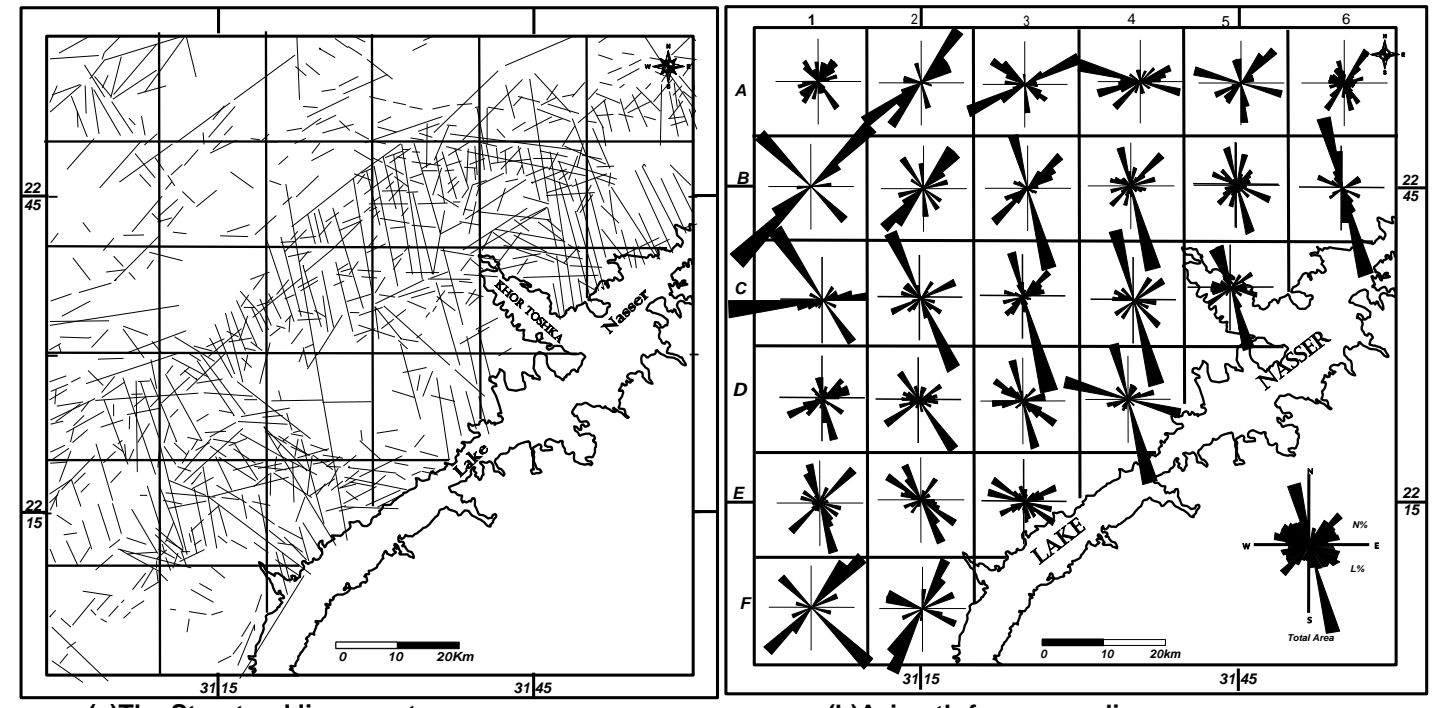

(a)The Structural lineaments map.

(b)Azimuth-frequency diagrams.
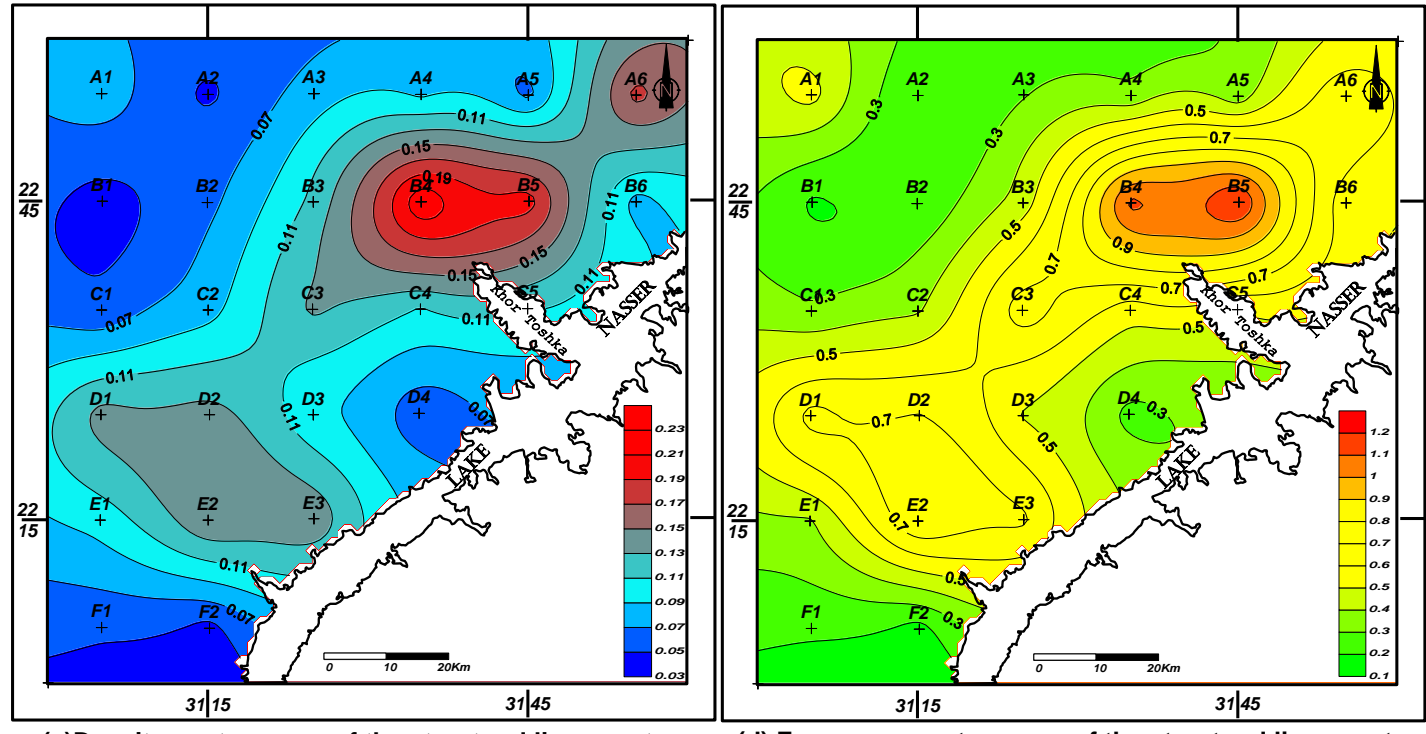

(c)Density contour map of the structural lineaments.

(d) Frequency contour map of the structural lineaments.

Fig. 10: Constructed structural lineaments maps for Tushka area. 


\section{Structural lineaments}

The structural lineaments map of the study area is constructed (Fig. 10a) following the structural lineaments map of Egypt prepared by El Shazly et al. ${ }^{[17]}$. The area of study is subdivided into unit areas of $10^{\prime}$ latitudes and 10' longitudes. They are marked vertically by letters A, B, C...etc., and horizontally by numbers 1, 2, 3 ...etc, (Fig. 10a). The azimuthfrequency diagrams for each unit area are represented in Fig. (10b). The structure controls of Khor Tushka (NNW-SSE and NW-SE ) that are related to the Red Sea rift are distinguished in area units B3, B4, B5, B6, $\mathrm{C} 1, \mathrm{C} 2, \mathrm{C} 3, \mathrm{C} 4, \mathrm{C} 5, \mathrm{D} 2, \mathrm{D} 3, \mathrm{D} 4$ and E2. It helps in recharging the Nubia Sandstone aquifer from Lake Nasser. On the other hand, the northern and western parts of the study area are affected by the NakhlaiAswan structure (NE-SW), which is more related to the Gulf of Aqaba structure than to the previous trend (NW-SE). This trend is recorded in the unit areas $\mathrm{A} 2$, A3, A4, A5, A6, B1, B2 and B3.

The cumulative data for the area of study reflect the dominance of the $\mathrm{N} 11-20 \mathrm{~W}$ trend which is a primary trend and represents $13.63 \%$ for the number and 21.53 $\%$ for the length. This means that the area under study is affected by the structure of Khor Tushka. The second most dominant trend is $\mathrm{N} 41-50 \mathrm{E}$ that represents $11.74 \%$ for the number and $10.45 \%$ for the length.

The frequency contour map reflects the impact of the structures and lithology (Fig. 10d), where the different rocks have different frequencies under the effect of the same structures. The frequency contour map reveals that the area units B4, B5, C3 and E2 have high frequency values which may be attributed to these unit areas are mainly covered by either Nubia sandstone was that affected by hydrothermal solutions, basalt extrusion and by the presence of basement rocks that have better characteristics, giving rise to a high structural lineament frequency on the surface. The low frequencies occur in the western and southeastern parts of the study area are attributed to the widespread occurrence of sand plains resulted from weathering and erosion processes. On the other hand, the structural density contour map (Fig. 10c) ravels that the high density areas are defined by units B4, B5, C3 and E2 having values of $1.27,1.21,0.75$ and $0.79 \mathrm{~km}^{-1}$, respectively. The unit areas A1, A2, A3, A4, A5, B1, B2, B3, C1 and C2 have low structural lineament density values of $0.53,0.2,0.29,0.33,0.34,0.18,0.21$, $0.44,0.31$ and $0.38 \mathrm{~km}^{-1}$, respectively. These low densities are related to the area covered by shale and clay of the Tushka depression in which structural lineaments are not propagated to the surface.

\section{Hydrogeological impacts}

The recorded Nubia Sandstone rock units in Tushka area are locally composed of porous and permeable sand and ferruginous sandstone with clay intercalations forming three successive water-bearing formations, namely; the Gilf, Abu Simble and Lake Nasser to the south of Khor Tushka. In the middle part of the study area, the groundwater exists under unconfined to semiconfined conditions (Fig. 11a). In the northern part of Khor Tushka the Gilf Formation overlies directly the Precambrian basement rocks (mainly granite) over which rests a succession of undifferentiated coarsegrained sandstones with a few gravel intercalations at its top and occasional argillaceous beds. Therefore, the groundwater north of Khor Tushka exists under unconfined conditions (Fig. 11b). The entire sedimentary succession shows vertical and lateral facies changes as well as thickness variations.

The constructed sand percent map of the Nubia Sandstone aquifer in the study area (Fig. 12a) indicates an increase in sand percent from $6.8 \%$ (within Tushka depression) to more than $70 \%$ (around Khor Tushka). This increase towards the southwest reflects an associated increase in the aquifer potentiality.

The petrographic study reveals that the exposed Nubia sandstones have, in most cases, well developed porosity ranging between 13-30\%. The pores are interconnected resulting in a good permeability and, thus, forming good aquifers for storing and transmitting groundwater.

Structurally, the tectonic activity brought the Precambrian basement rocks (Nakhlai-Aswan uplift) at a higher elevation forming an irregular continuity of the aquifer units with possible connection through faults. The Nubia Sandstone aquifer was developed into a local basin with hydraulic connections. New recharge from Lake Nasser having fresh groundwater similar to the Nile water mixed with the other groundwater originated from the regional remote source of the recharge with higher groundwater salinities (Fig. 11a). Moreover, the fault systems and structural lineaments play an important role in recharging the groundwater aquifers in the studied area. The NW-SE and E-W faults act as conduits which transmit the groundwater within the local aquifer and the regional system (Korany et al., 2012 , in press). This impact is clearly recognized at the production wells located closer to the faults as PW-11', PW-13 and PW51 where the average transmissivity is 1258,1236 and $1637 \mathrm{~m}^{2} /$ day, respectively. It is worthmentioning that the NW-SE structural lineaments trend, which is the most dominant in the study area, help in recharging the Nubia Sandstone aquifer from Lake Nasser as confirmed from the flow net map of the study area (Fig. 12b).

\section{Conclusions}

The surface of Tushka area is made up of a sedimentary succession ranging from the Paleozoic to Quaternary. It is underlained by Precambrian basement rocks that are well exposed to the west. The Paleozoic rocks are encountered only in the subsurface in the deep wells. They are composed mainly of brown mudstone and sandstone. The Lower Cretaceous rocks could be easily classified (from base to top) into the Abu Simble, Lake Nasser and Sabaya formations. The Abu Simble Formation is composed of a sequence of fluviatial sand- 
stone that is thin-laminated and cross-bedded and contains petrified wood. The Lake Nasser Formation is made up of a laminated sequence of ferruginous siltstone, sandstone and ferruginous sandstone. The Sabaya Formation is composed mainly of sandstone and ferruginous sandstone with thin beds of conglomerate in its lower part and siltstone and fine sandstone intercalated with thin beds paleosol in its upper part. The Upper Cretaceous rocks are represents by the Kiseiba Formation that is made up of a succession of shale alternating with a few beds of siltstone in the lower part, while the upper part becomes more carbonaceous and is composed of fossilferrous limestone and marl. The Nubia sandstone aquifer system in the subsurface is built up of porous and permeable successions of the Gilf, Abu Simble and Lake formations. In the middle and southern parts of Khor Tushka, the groundwater exists under unconfined to semi-confined conditions as the aquifer contains some clay intercalations within the sandstone succession. The Northern part is characterized by unconfined conditions. They are connected hydraulically both laterally and vertically where the geological properties and the dominating structural deformation provide more confidential supports for the development of a good aquifer with a new developed recharge from Lake Nasser.

The studied Nubia sandstones are mainly arenites and less commonly wackes. In most cases they show well developed porosity ranging between 10-28\%. The pores are interconnected giving rise to good permeability and, thus, form good groundwater aquifers in the studied area.

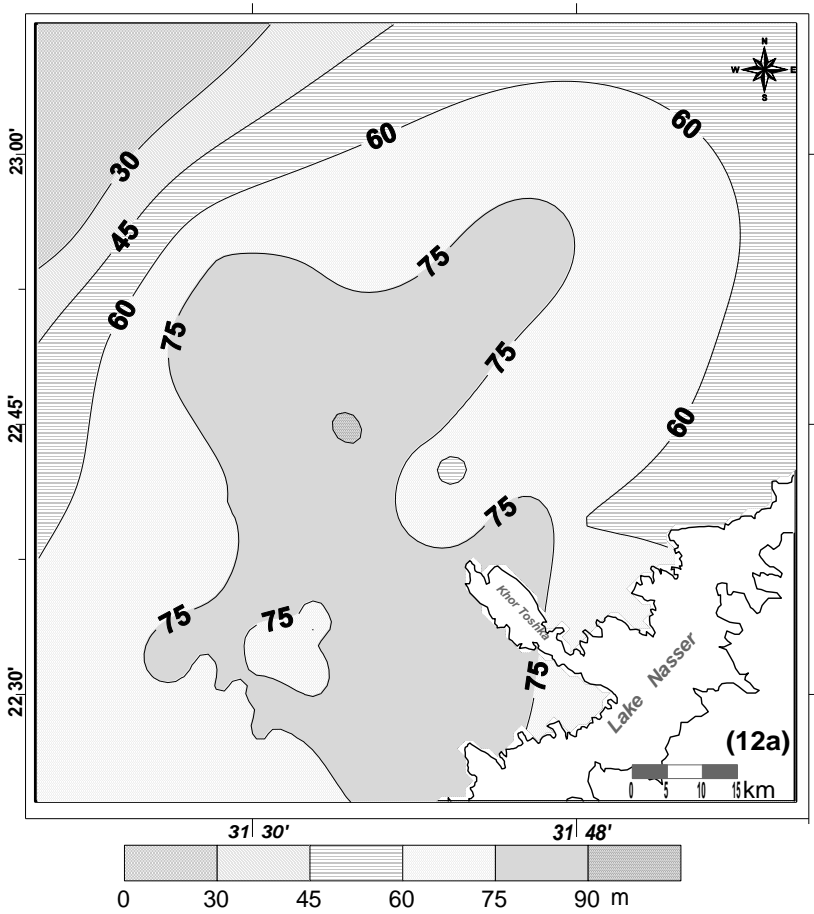

Fig. 12a: Sand percent map for Tushka area.
Various structural elements are present among which are the uplift of the basement, the structural lineation, folds and the ring forms. These have proper impacts upon the groundwater occurrences. The fault systems play an important role in recharging the groundwater aquifers from Lake Nasser especially the NW-SE. They act as conduits and help in transmitting the groundwater within the study area supporting the hydraulic connection between the aquifer units.
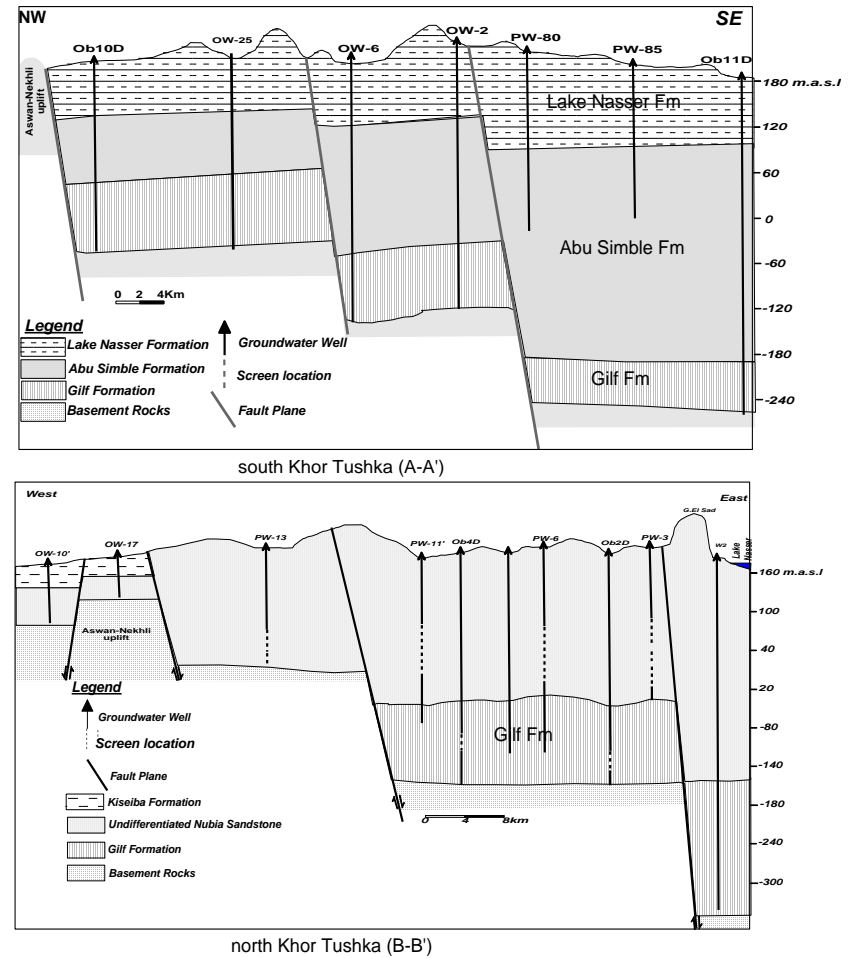

Fig. 11: Geological cross-sections south and north of Khor Tushka.

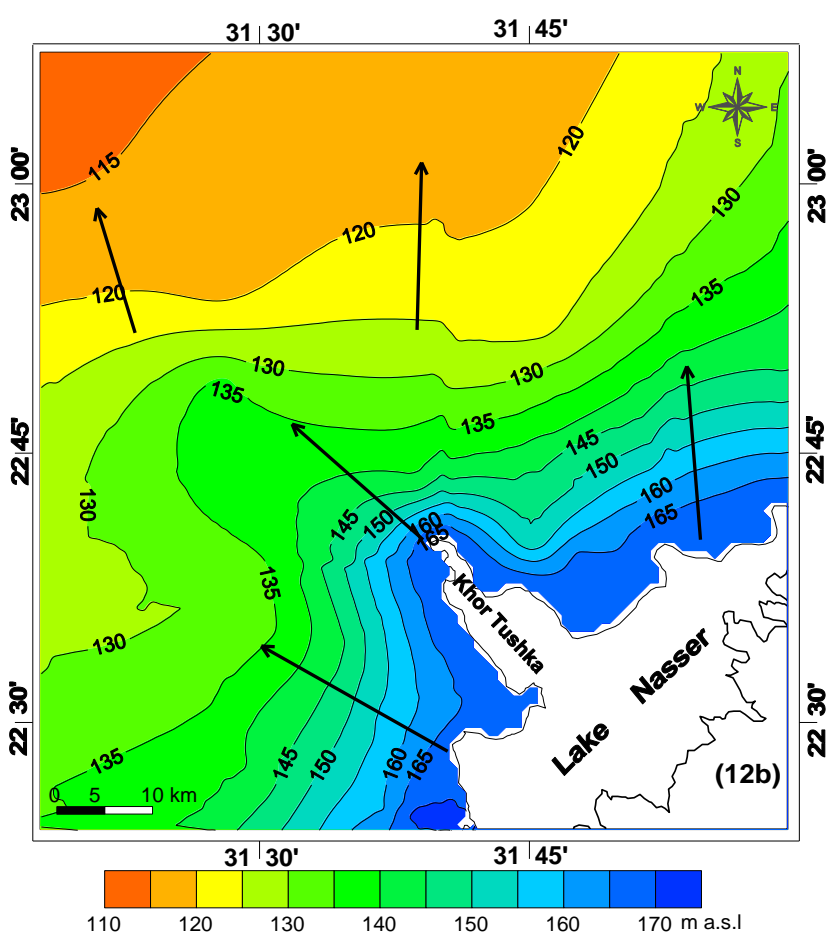

Fig. 12b: Piezometric surface map (May 2010) 


\section{References}

1) Rüssegger J.R. (1837). Kreide und Sandstein Einfluss von Granit auf letzteren [Chalk and sandstone: the influence of granite on the latter]. N Jb Mineral 1837: 665-669.

2) Attia M.I. (1955). Topography, geology and iron ore deposits of the district east of Aswan. Geol. Surv. Egypt, p266.

3) El Naggar Z.R. (1970). On a proposed lithostratigraphic subdivision for Late CretaceousEarly Paleocene succession in the Nile Valley, Egypt. U.A.R. 7th. Petrol. Conf., Kuwait, paper No. 64 (B-3).

4) Issawi B. and Jux U. (1982). Contribution to the stratigraphy of Paleozoic rocks in Egypt. The Geol. Surv. Egypt, paper No. 64.

5) El Nasharity F.A. (1985). Contribution to the geology and structure of Adindan area, south Eastern Desert, Egypt. The Geol. Soci. Egypt, Abstract, p 18-19.

6) Klizsch E., Harms J., Legal-Nicol A. and List F. (1986). Major subdivision and depositional environments of Nubia strata, southwestern Egypt, Am. Ass. Petr. geol. Bull., 63(6): 937-974.

7) Ahmed S.M., Al-sheikh H.A. and Osman R.A. (1993). Facies and depositional enviroments of the Pre-Maastrichtian clastic rocks of west and southwest Aswan, Egypt. Egypt. j. Geol., 37: 69-96.

8) Issawi B. and Osman R. (1993). Tectonosedimentary synthesis of Paleozoic-Cretaceous clastic, southwest Aswan, Egypt. Egypt Sedimentology, I: 11-31.

9) Geoistrazivanja Company, (1965). Supply and installation of 33 piezometers within the High Aswan Dam Reservoir area, Zagreb, Yugoslavia, parts, I-8.
10) CONOCO (Continental Oil Company), (1987). Geological map of Egypt (scale 1: 500,000). Conoco Inc. in collaboration with Freie Universitat Berlin, El Sad Ali sheet.

11) Sultan M., Chamberlain K.R., Bowring S.A., Arvidson R.E., Abuzied H. and El Kaliouby B. (1990). Geochronologic and isotopic evidence for invovement of pre-pan-African crust in the Nubian Shield, Egypt. Jour. Geol. 18: 761-764.

12) Research Institute for Groundwater (RIGW), 19982000. Technical Reports for the drilled wells in Tushka area, Phase III, Res. Inst. Ground. Cairo.

13) Issawi B. (1978). Geology of Nubia West area, Western Desert, Egypt. Ann Geol Surv Egypt 8: 237-253.

14) Korany E.A, Aggour T.A., Mosaad S., Kehew A.E. and Salim A.A., (In Press 2012). Hydrogeological impacts of recent recharge to Nubia sandstone aquifer in Tushka-Abu Simble area, Western Desert, Egypt. Egypt. Jour. Geol., 56: 33-51.

15) Barthel K.W. and Boettcher R. (1978). Abu Ballas Formation (Tithonian Berriasian; Southwestern Desert, Egypt) a signficant lithostratigraphic unit of the former "Nubian Series" Mill. Bayer. Staatsslg. Palaont. Hist. Geol., 18: 153-166.

16) Pettijohn F.J., Potter P.E. and Siever R. (1987). Sand and Sandstone. Springer, New York, 553 p.

17) El Shazly E.M., Abdel Hady M.A., El Ghawaby M.A., Salman A.B., El Kassas I.A., Khawasik S.M., El Amin H., El Rakaiby M.M, El Aassy I.E., Abdel Magid A.A. and Mansour S.I., (1980). Structural lineation maps of Egypt, scale 1:1000,000. Acad. of Scie. Res. and Tech., Remote Sensing Center, Cairo, Egypt. 